\title{
RARE EARTH ELEMENT ABUNDANCES IN CARBONATITES AND FENITES OF THE NEWANIA COMPLEX, RAJASTHAN, INDIA
}

\author{
S. G. VILADKAR and P. B. PAWASKAR
}

\begin{abstract}
VILADKAR, S. G. and PAWASKAR, P. B., 1989: Rare earth element abundances in carbonatites and fenites of the Newania complex, Rajasthan, India. Bull. Geol. Soc. Finland 61, Part 1, 113-122.

The Newania carbonatite is intrusive into the Untala granite-gneiss of Precambrian age. An aureole of dominantly sodic fenites has been developed around the carbonatite. The primary dolomitic carbonatite magma has differentiated to ankeritic carbonatite and the latter has intruded, and in the process metasomatically replaced the former all along the intrusive contact. The rare earth element abundances show increases in total REE with LREE enrichment from coarse grained early dolomitic carbonatite to younger ankeritic carbonatite. However, the highest REE abundances are found in a dolomitic carbonatite rich in pyrochlore, zircon and $\mathrm{Nb}$-silicate. Among the minerals in carbonatites the cumulate apatite shows the highest REE abundances while amphibole shows the lowest REE abundances. Magnetite and dolomite phenocryst show intermediate REE values. During fenitization of the Untala granite - gneiss to syenitic fenites, REEs have been added to the country rock with LREEs > HREEs; and REEs behaved coherently during the process of fenitization.

Key words: Carbonatites, fenite, rare earths, Proterozoic, Newania, Rajasthan, India.

S. G. Viladkar, Geology Department, St. Xavier's College, Bombay-400 $001 /$ India. P. B. Pawaskar, Analytical Chemistry Division, Bhabha Atomic Research Centre, Trombay, Bombay-400 085/India.
\end{abstract}

\section{Introduction}

About $45 \mathrm{~km}$ east of Udaipur city in Rajasthan lies the Newania carbonatite-fenite complex (Fig. 1) of Precambrian age $(959 \pm 24 \mathrm{Ma}$, Deans and Powell 1968). The oblong shaped carbonatite is largely dolomitic with a wide aureole of predominantly sodic fenitization and lacking associated alkaline rocks. A brief description of the complex was earlier given by Deans and Powell (1968) and Phadke and Jhingran (1968). Fenites were first studied by Viladkar (1980) while recently Viladkar and Wimmenauer (1986) published a more detailed account of carbonatites and fenites. The present work is concerned with the rare earth element abundances in carbonatite, minerals in carbonatites and fenites.

\section{General geology and Petrography}

The carbonatite outcrop, striking WNW with an average dip of $40^{\circ}$ towards SSE, swells in the central part and its width diminishes gradually at both ends. The emplacement of carbonatite has not produced any major structural disturbances in the surrounding rocks and thus appears to have occupied a zone of structural weakness 


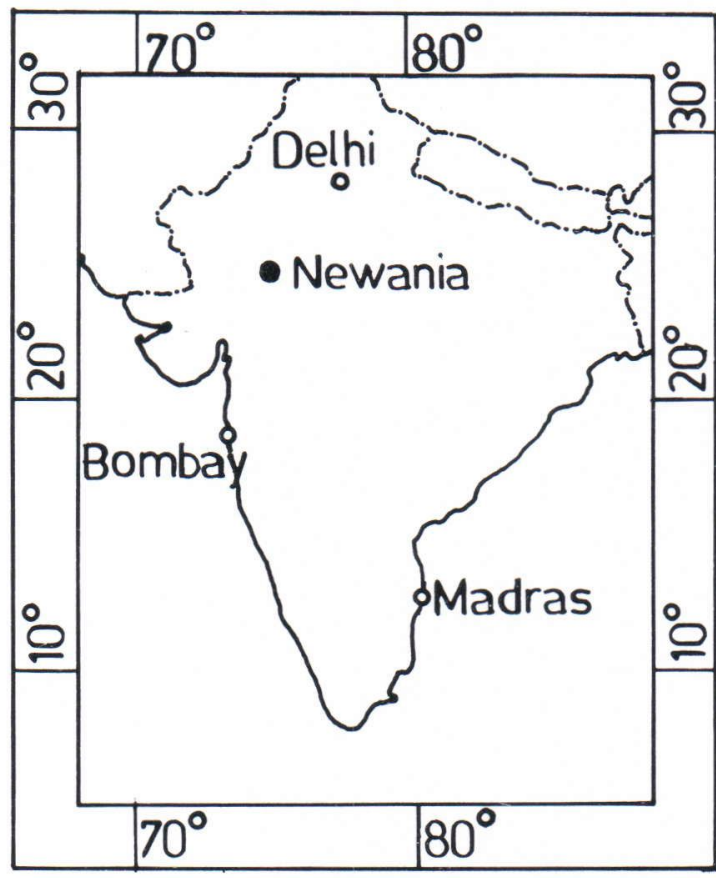

Fig. 1. Location map of the Newania complex.

within the Precambrian gneiss. Along its contact with the country rock the carbonatite shows brecciation. Some breccia plugs are also encountered within the carbonatite outcrop. From the composition of different fragments in the breccia it is clear that they are derived from the basement gneiss, fenites and the cumulate apatite rocks.

There are at least three phases of dolomitic carbonatite intrusions and the evidence of their being different phases is provided by xenoliths of the earlier phase in the later ones. The first phase is of coarse dolomitic carbonatite with more than $96 \%$ modal carbonate $(32 \mathrm{Ne})$. This is intruded by a second phase of medium to fine grained type which tends to be porphyritic $(28 \mathrm{Ne})$, with at times a phenocryst content ranging between $30 \%$ to $45 \%$. Megacrysts of dolomite $(3 \times 5 \mathrm{cms})$ occur in the fine grained matrix. The third phase of dolomitic carbonatite is marked by the presence of sodic amphibole, phlogopite, zircon, pyrochlore and $\mathrm{Nb}$-silicate $(24 \mathrm{Ne})$, in addition to apatite and magnetite which are ubiquitous in dolomitic carbonatites. Euhedral octahedral to subhedral grains of magnetite at times reach high concentrations (e.g. $16 \mathrm{Ne}$ ). The carbonatite outcrop shows the presence of distorted bands and streaks of apatite all over the length of the outcrop but particularly abundant in the central part. The banding is also accentuated by the presence of magnetite, sodic amphibole and phlogopite. Some of the bands are very rich in zircon and pyrochlore which stand out prominently, being darker in colour. The dolomitic carbonatite has been intruded by the ankeritic carbonatite and in the process has been metasomatically replaced all along the contact. The process of replacement is well observed in thin sections where small and large crystals of dolomite are progressively replaced by the ankeritic solutions from the rims towards centre. The relict patches of the original dolomite are often seen in the matrix made up of ankeritic carbonatite. Specimen No. $26 \mathrm{Ne}$ is one such example which shows the maximum effects of metasomatism. The ankeritic solutions must be very hydrous as most of the amphibole and phlogopite in such rocks have been converted to chlorite. The ankeritic carbonatites, in general, are non-porphyritic, medium to fine grained rocks. Amongst the accessory minerals the most common is apatite; magnetite attains a high proportion in some but is totally absent in others. The youngest phase in the carbonatite sequence, also ankeritic in composition, seems to have intruded much later, with a sharp contact between the earlier phase carbonatite and fenites. These dykes are dark brown to black in colour and mono-mineralic in composition.

The most conspicuous feature of the Newania complex is the strong sodic fenitization of the country rock granite-gneiss all along its contact with the carbonatite. Although the entire fenite zone is highly weathered, good samples can be obtained from the relatively fresh boulders and a trench dug in the fenite aureole. Along this trench one can trace the strong sodic fenitization near the carbonatite contact which decreases in 


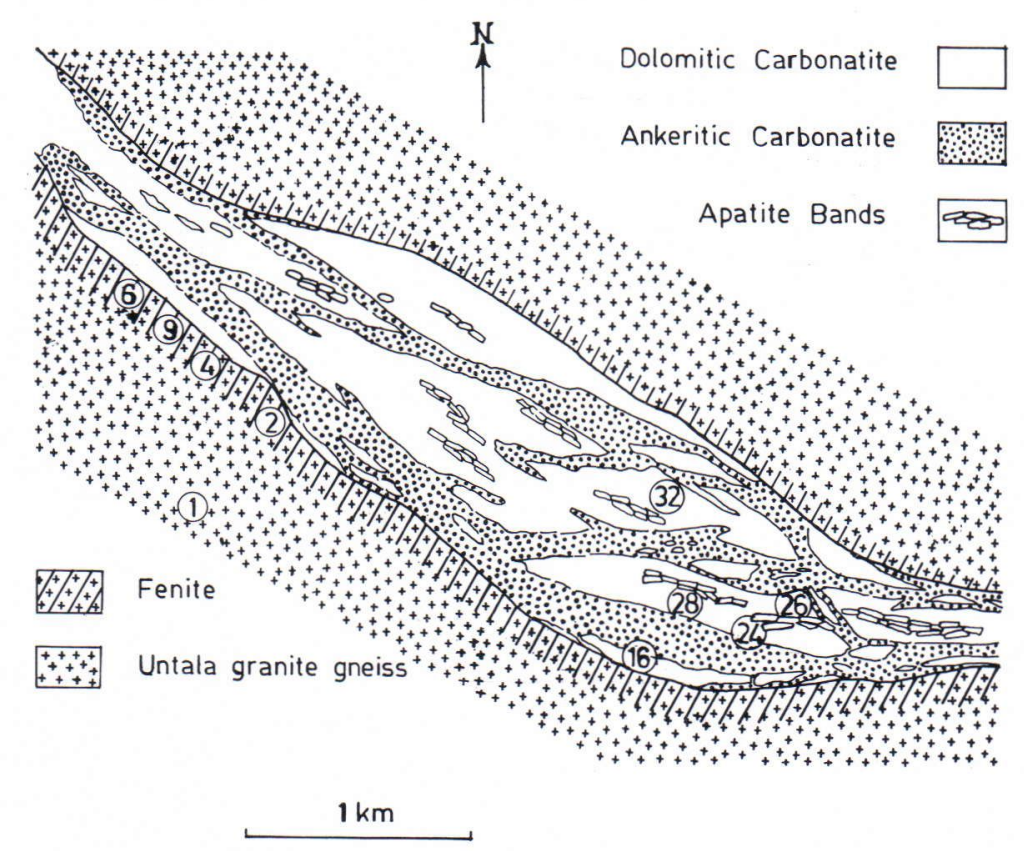

Fig. 2. Sketch map of the Newania complex with locations of samples analysed for REE.

intensity as one moves away from the contact, and finally at a distance of about 75 meters the effects of fenitization are practically negligible. The fenites are highly inhomogeneous. At times they are so mafic that the light coloured feldspars are seen only as pools surrounded by dark green sodic amphibole, while on the other hand, the samples collected in proximity to such sodic, amphibole-rich fenites are so leucocratic that the sodic amphibole occurs as isolated patches. These leucocratic fenites become monomineralic, composed entirely of $\mathrm{K}$-feldspar (Or $>90 \%$ ) with stray grains of apatite and calcite.

The Untala granite-gneiss is very uniform in composition (1 Ne) being composed mainly of feldspar and quartz, while biotite occurs as an acceessory in some samples. The gneissic texture is well preserved in poorly fenitized as well as in some syenitic fenites. In poorly fenitized rocks $(2 \mathrm{Ne})$, both quartz and feldspar show granulation and wavy extinction; the former also develops biaxiality. Turbidity develops in microcline. Biotite shows alteration to limonite while quartz is slowly replaced by sodic amphibole but still preserving its original form.

In the medium grade fenites modal amphibole increases as stubby prisms and thin veins cutting across original quartz and feldspar. Microcline starts losing its characteristic cross hatching and gradually converts into orthoclase. The newly formed orthoclase is without turbidity. Albite also forms at the expense of quartz. Sodic amphibole takes prismatic shape.

In the advanced stage of fenitization, the syenitic fenite is essentially composed of orthoclase (Or $>90 \%$ ) and sodic amphibole. Zoning is common in amphiboles of some syenitic fenites.

Six samples of carbonatites and five of fenites were selected for the REE study. Besides dolomite, apatite, magnetite and sodic amphibole from carbonatites have also been analysed for their REE content. The location of carbonatites and fenites are shown in Fig. 2 and their modal compositions are given in Tables 1 and 2 respectively. 
Table 1. Modal composition of carbonatites from Newania.

\begin{tabular}{|c|c|c|c|c|c|c|c|}
\hline Sp. No. & $16 \mathrm{Ne} / \mathrm{A}$ & $28 \mathrm{Ne}$ & $26 \mathrm{Ne}$ & $24 \mathrm{Ne}$ & & $32 \mathrm{Ne}$ & $10 \mathrm{Ne}$ \\
\hline Carbonate & 68.8 & 80.1 & 66.0 & 69.9 & & 96.6 & 79.8 \\
\hline Apatite & 17.2 & 4.4 & 25.5 & 10.0 & & 1.2 & 5.5 \\
\hline Magnetite & 12.8 & $15.5^{+}$ & $8.5^{*}$ & 4.0 & & 2.2 & 6.8 \\
\hline Amphibole & 1.2 & - & - & 11.2 & & - & 4.2 \\
\hline Phlogopite & - & - & - & 2.0 & & - & 3.7 \\
\hline Pyrochlore & - & - & - & 3.5 & ++ & - & - \\
\hline
\end{tabular}

* includes $2.4 \%$ hematite

+ includes $9.4 \%$ hematite

${ }^{++}$also present are traces of zircon, Nb-silicate and columbite

16 to $32 \mathrm{Ne}-$ dolomitic carbonatites, $10 \mathrm{Ne}-$ ankeritic carbonatite

Table 2. Modal composition of Newania fenites

\begin{tabular}{lrrrrr}
\hline Sp. No. & $1 \mathrm{Ne}$ & $2 \mathrm{Ne}$ & $4 \mathrm{Ne}$ & $6 \mathrm{Ne}$ & $9 \mathrm{Ne}$ \\
\hline Quartz & 41.6 & 24.8 & 3.00 & - & - \\
Feldspar & 56.2 & 67.4 & 80.8 & 63.1 & 60.3 \\
Amphibole & - & 6.0 & 12.0 & 24.6 & 31.1 \\
Biotite & 2.2 & 1.8 & - & - & - \\
Apatite & - & - & - & 1.8 & 1.4 \\
Iron oxide & - & - & 4.2 & 3.1 & 2.5 \\
Carbonate & - & - & - & 7.4 & 4.7 \\
\hline
\end{tabular}

1Ne: Unfenitized Untala-granite-gneiss; $2 \mathrm{Ne}$ : Mildly fenitized granite-gneiss; $4 \mathrm{Ne}-9 \mathrm{Ne}$ syenitic fenites

\section{Analytical method}

The sequential analytical procedure adopted in the present work is as follows:

1. Weighing and sealing of samples, reference rock standards and elemental standards in a clean, independent double sealed polythene bags.

2. Longer irradiation followed by sequential counting for long lived nuclides.
Irradiations have been carried out in the APASARA Reactor, Bhabha Atomic Research Centre, Trombay, Bombay. The counting assembly consists of a $\mathrm{Ge}(\mathrm{Li})$ detector $(120 \mathrm{cc})$ with resolution (FWAM) of $2-3 \mathrm{KeV}$ at $1332 \mathrm{KeV}$ gamma-ray coupled to 1024 channel analysis (Murali et al. 1979).

\section{REE abundances in minerals and rocks}

\section{Minerals in carbonatites}

REE abundances in megacrysts of dolomite, cumulate apatite and sugary white concentrations of apatite, magnetite and sodic amphibole from carbonatites have been determined (Table 3) and their chondrite normalized patterns are shown in Fig. 3. The sodic amphibole has the lowest REE content among all minerals analysed, while both apatite fractions have the highest REE abundances. REE abundances in magnetite and dolomite are higher than in the associated sodic am-

Table 3. REE abundances in minerals from Newania carbonatite (in ppm)

\begin{tabular}{lrrrrrrrrr}
\hline Sp. No. & La & Ce & Nd & Sm & Eu & Tb & Yb & Lu & $\Sigma R E E$ \\
\hline A1 & 1424 & 3726 & na & 372 & 100 & 33.6 & 12 & 0.48 & 5668 \\
A2 & 1950 & 5271 & 2100 & 412 & 97 & 7.3 & 12.5 & 1.8 & 9851.6 \\
X & 43 & 105 & 15 & 9 & 2.7 & 0.5 & 1.2 & 0.15 & 176.5 \\
Mt & 46 & 85 & 66 & 8.2 & 1.32 & 0.42 & 0.63 & 0.20 & 207.7 \\
Amp & 2.3 & nd & nd & 3 & 2 & nd & 0.6 & nd & 7.9 \\
\hline
\end{tabular}

A1: Surgary-white concentration of apatite in dolomitic carbonatite; A2: Cumulate apatite; X: Megacryst of dolomite; Mt: Magnetite; Amp: Amphibole from dolomitic carbonatite. 


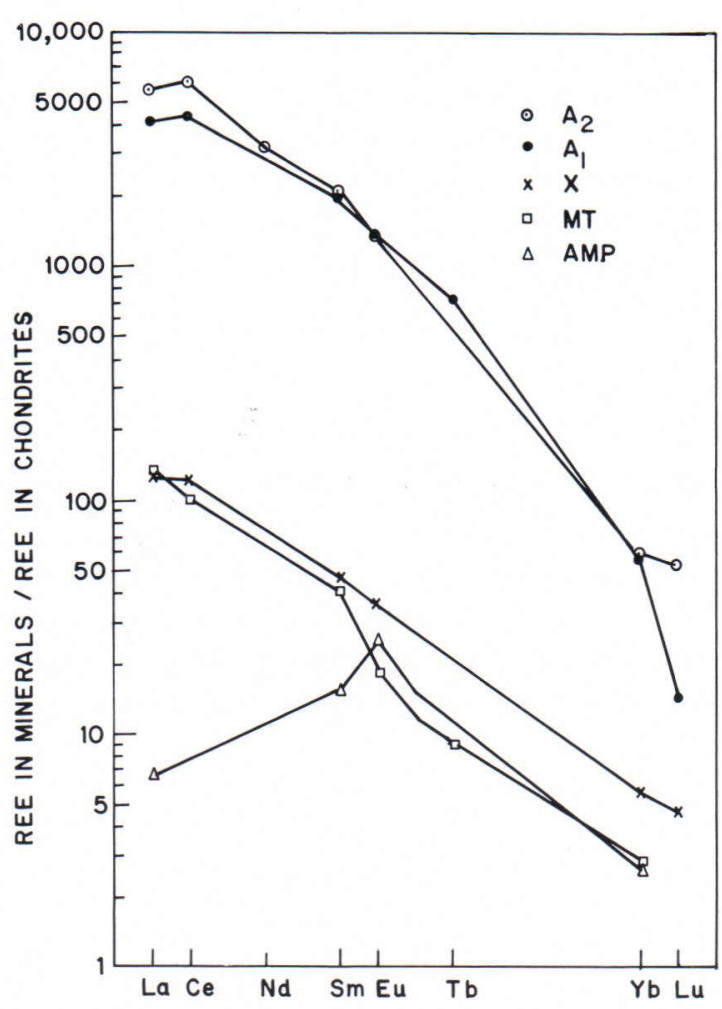

Fig. 3. Chondrite normalized REE distribution patterns of minerals from carbonatites: A2 - cumulate apatite, A1 sugary white apatite concentrations in dolomitic carbonatite, $\mathrm{X}$ - megacryst of dolomite in dolomitic carbonatite, MT magnetite from dolomitic carbonatite, AMP - amphibole from dolomitic carbonatite.

phibole but considerably lower than the apatites, and both show almost identical REE distribution patterns although magnetite shows a steeper middle and HREE pattern. The sodic amphibole shows a small positive Eu anomaly. Both apatite fractions are strongly enriched in total REEs and LREEs in comparison to the associated minerals in carbonatites which have crystallized later than the apatite. As pointed out by Andersen (1987) apatite fractionation can deplete carbonatite magma in LREEs. Eby (1975) reported a negative $\mathrm{Eu}$ anomaly for apatite from the Oka carbonatite; the Newania apatite however, shows no Eu anomaly.

\section{Carbonatites}

The REE abundances in five dolomitic carbonatites and one ankeritic carbonatite $(10 \mathrm{Ne})$ are shown in Table 4, and their chondrite normalized distribution patterns along with that of carbonate phase are plotted in Fig. 4. Among the dolomitic carbonatites, $32 \mathrm{Ne}$ which consists of more than $96 \%$ dolomite has a distribution pattern similar to that of a pure dolomite phase but contains more total REE abundances. The highest REE abundances and also the LREE enrichment is seen in a dolomitic carbonatite which shows a relatively large amount of modal apatite, pyrochlore and zircon $(24 \mathrm{Ne})$. The other carbonatite samples lacking in these minerals have considerably lower REE abundances. The ankeritic carbonatite $(10 \mathrm{Ne})$ shows a distribution pattern similar to the dolomitic carbonatite but a steeper slope towards HREE. The samples

Table 4. REE abundances in Newania carbonatites (in ppm)

\begin{tabular}{lrrrrrlllll}
\hline Sp. Nos. & La & Ce & Nd & Sm & Eu & Tb & Yb & Lu & REE & La/Yb \\
\hline $32 \mathrm{Ne}$ & 56 & 114 & 60 & 11 & 3.22 & 0.74 & nd & 0.18 & 245.14 & - \\
$26 \mathrm{Ne}$ & 122 & 212 & 54 & 17.8 & 8.2 & 1.5 & 1.5 & 0.1 & 417.1 & 81.3 \\
$16 \mathrm{Ne}$ & 80 & 209 & 42 & 12.7 & 4.17 & 0.95 & nd & 0.15 & 348.97 & - \\
$28 \mathrm{Ne}$ & 108 & 215 & 52 & 12.7 & 3.49 & 1 & 0.73 & 0.17 & 393 & 147.9 \\
$24 \mathrm{Ne}$ & 545 & 2680 & 455 & 52.3 & 28.4 & 5.7 & 2.6 & 0.44 & 3769.44 & 209.6 \\
$10 \mathrm{Ne}$ & 153 & 182 & na & 8.7 & 4.2 & 0.7 & 0.64 & 0.11 & 349.5 & 239 \\
\hline
\end{tabular}

na $=$ not analysed, nd $=$ not detected

$32 \mathrm{Ne}$ - coarse grained dolcmitic carbonatite; $26 \mathrm{Ne}$ - dolomitic carbonatite showing maximum effects of metasomatism by ankeritic carbonatite; $16 \mathrm{Ne}$ - dolomitic carbonatite rich in magnetite and apatite; $28 \mathrm{Ne}$ - fine grained porphyritic dolomitic carbonatite; $24 \mathrm{Ne}$ - dolomitic carbonatite with bands of silicate minerals which also include pyrochlore, zircon and $\mathrm{Nb}$-silicate; $10 \mathrm{Ne}$ - ankeritic carbonatite 


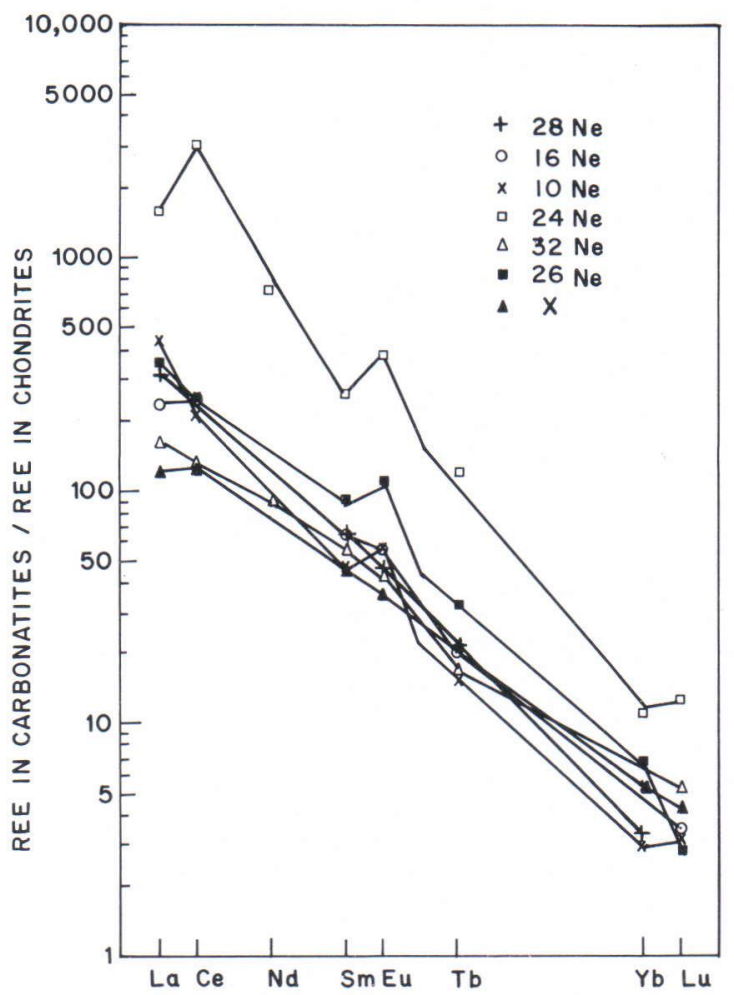

Fig. 4. Chondrite normalized REE distribution patterns of Newania carbonatites: sample numbers and description of samples is same given below Table 4; in addition filled triangle shown, represents $\mathrm{X}-$ megacryst of dolomite.

$26 \mathrm{Ne}, 24 \mathrm{Ne}, 16 \mathrm{Ne}$ and $10 \mathrm{Ne}$ show a small positive Eu anomaly. Except $26 \mathrm{Ne}$, the other three samples show the presence of modal sodic amphibole and phlogopite and it may be possible that these minerals may have caused the positive
Eu anomaly. The other samples of carbonatites lacking in modal sodic amphibole and phlogopite also lack Eu anomalies. The chondrite normalized distribution patterns exhibit scatter at both LREE and HREE ends, with crowding around middle REE. The ankeritic carbonatite has the highest $\mathrm{La} / \mathrm{Yb}$ ratio.

\section{Fenites}

REE abundances in an unfenitized granitegneiss (1 Ne), a mildly fenitized gneiss ( $2 \mathrm{Ne})$, a leucocratic syenitic fenite $(4 \mathrm{Ne})$ and two syenitic fenites with high modal sodic amphibole ( $9 \mathrm{Ne}$ and $6 \mathrm{Ne}$ ) are given in Table 5, and their chondrite normalized distribution patterns are shown in Fig. 5.

The Untala granite-gneiss has the lowest REE abundances and a prominent negative Eu anomaly. The mildly fenitized gneiss shows a positive Eu anomaly while three syenitic fenites show no Eu anomaly. Some significant observations can be made in case of Newania fenites: 1. Total REE abundances increase in order from a midly fenitized rock to leucocratic syenitic fenite to syenitic fenites rich in sodic amphibole, 2. REEs behaved coherently during fenitization resulting in parallel chondrite normalized distribution patterns and, 3. LREEs are added more abundantly than HREEs, indicating a greater mobility of the former. This is in agreement with the earlier observations by Martin et al. (1978), Eby (1975), and Viladkar and Dulski (1986). Plots of Ce, La, $\mathrm{Nd}, \mathrm{Sm}$ and $\mathrm{Yb}$ against Si reveal increases in the

Table 5. REE abundances in the fenites and unfenitized gneiss of Newania

\begin{tabular}{|c|c|c|c|c|c|c|c|c|c|c|}
\hline Sp. Nos. & $\mathrm{La}$ & $\mathrm{Ce}$ & $\mathrm{Nd}$ & $\mathrm{Sm}$ & $\mathrm{Eu}$ & $\mathrm{Tb}$ & $\mathrm{Yb}$ & $\mathrm{Lu}$ & REE & $\mathrm{La} / \mathrm{Yb}$ \\
\hline $1 \mathrm{Ne}$ & 10 & 23 & na & 3.34 & 0.3 & 1 & 5 & 0.7 & 43.4 & 2 \\
\hline $2 \mathrm{Ne}$ & 64 & 119 & na & 3.18 & 1.22 & 0.42 & 1.3 & 0.15 & 189.27 & 49.2 \\
\hline $4 \mathrm{Ne}$ & 46 & 84 & 30 & 3.9 & 1.1 & 2.7 & 0.55 & 0.09 & 168.3 & 83 \\
\hline $6 \mathrm{Ne}$ & 123 & 284 & 104 & 17.5 & 5 & 1.2 & 0.95 & 0.13 & 535.78 & 129 \\
\hline $9 \mathrm{Ne}$ & 133.7 & 220 & 50 & 7.8 & 2.24 & 0.8 & 0.84 & 0.11 & 415.49 & 159 \\
\hline
\end{tabular}

na $=$ not analysed

$1 \mathrm{Ne}$ - Unfenitized Untala granite-gneiss; 2Ne - Mildly fenitized Untala granite-gneiss; 4Ne - Leucocratic syenitic fenites; $6 \mathrm{Ne} \& 9 \mathrm{Ne}-$ Syenitic fenites 


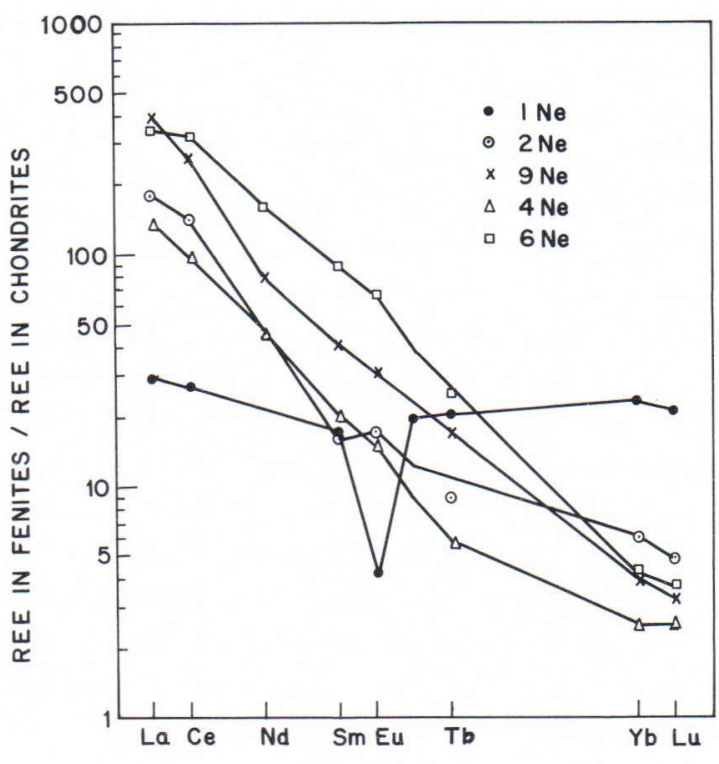

Fig. 5. Chondrite normalized distribution patterns of a protolith and fenites of Newania: $1 \mathrm{Ne}$ - unfenitized Untala granite-gneiss, $2 \mathrm{Ne}-$ mildly fenitized granite-gneiss, $4 \mathrm{Ne}-$ leucocratic syenitic fenite, $6 \mathrm{Ne} \& 9 \mathrm{Ne}$ - syenitic fenites with high modal sodic amphibole.

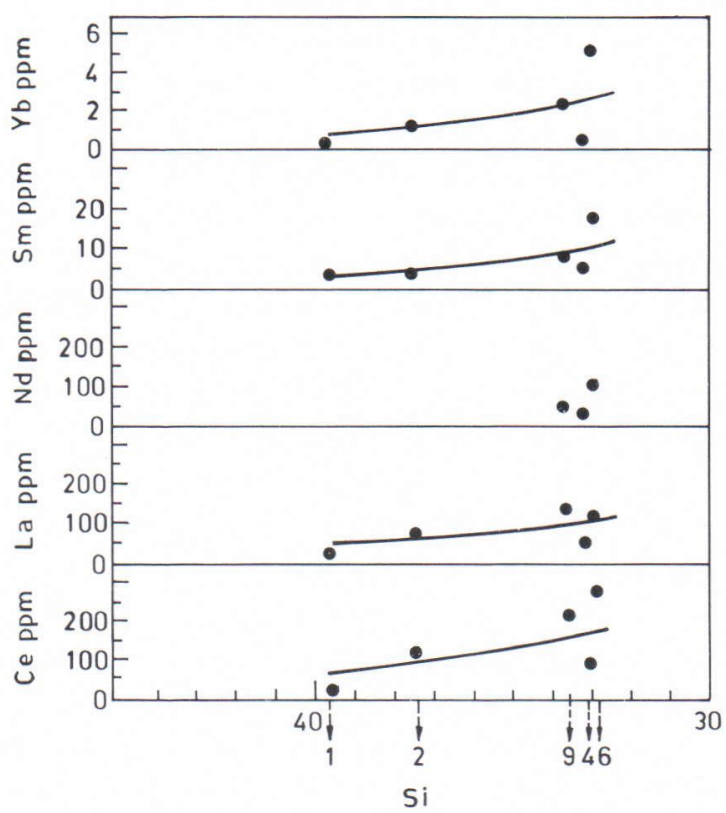

Fig. 6. Plots of concentrations of $\mathrm{Ce}, \mathrm{La}, \mathrm{Nd}, \mathrm{Sm}$ and $\mathrm{Yb}$ vs $\mathrm{Si}$ cations per 100 anions in fenites. content of these elements with a corresponding decrease in Si (Fig. 6).

\section{Discussion}

The intrusive nature and the wide aureole of fenitization around the Newania carbonatite confirms its magmatic origin. This is further supplemented by the $\mathrm{Sr}$ isotope data given by Deans and Powell $\left(1968,{ }^{87} \mathrm{Sr} /{ }^{86} \mathrm{Sr}=0.7034\right.$ and $0.7021)$. Field relations between dolomitic carbonatite and the ankeritic carbonatites clearly point to the younger age of the latter in the carbonatite sequence.

To study the behaviour of REEs during the process of fractionation we selected different phases of carbonatites. Our study reveals that the monomineralic coarse grained dolomitic carbonatite (oldest in the sequence) has the lowest REE abundances (32 Ne, total REEs $245 \mathrm{ppm}$ ), whereas the ankeritic carbonatite (younger in the sequence) has much higher total REE abundances (10 Ne, total REEs 349 ppm). However, the highest REE abundances are seen in a dolomitic carbonatite which is rich in zircon, pyrochlore, and $\mathrm{Nb}$-silicate in addition to apatite (24 Ne, total REE 3769 ppm). Viladkar and Wimmenauer (1986) have shown that both pyrochlore and zircon in these rocks show high concentrations of Ce. All other dolomitic carbonatites (except $24 \mathrm{Ne}$ ) are mineralogically similar with a slight variation in the content of apatite and magnetite. The ones with very low modal apatite and magnetite also show low REE abundances. This evidence is sufficient to conclude that the content of REE in the Newania carbonatites is mainly controlled by the mineralogy of these rocks.

Review of the literature shows that primary dolomitic carbonatites are comparatively rare, of which Newania and Sarfatoq perhaps provide good examples. Fen rauhaugite is also compositionally similar to the Newania and Sarfartoq, but as Le Bas pointed out (in Woolley, 1982) »- - - the Fen rauhaugite is a very mixed rock, 


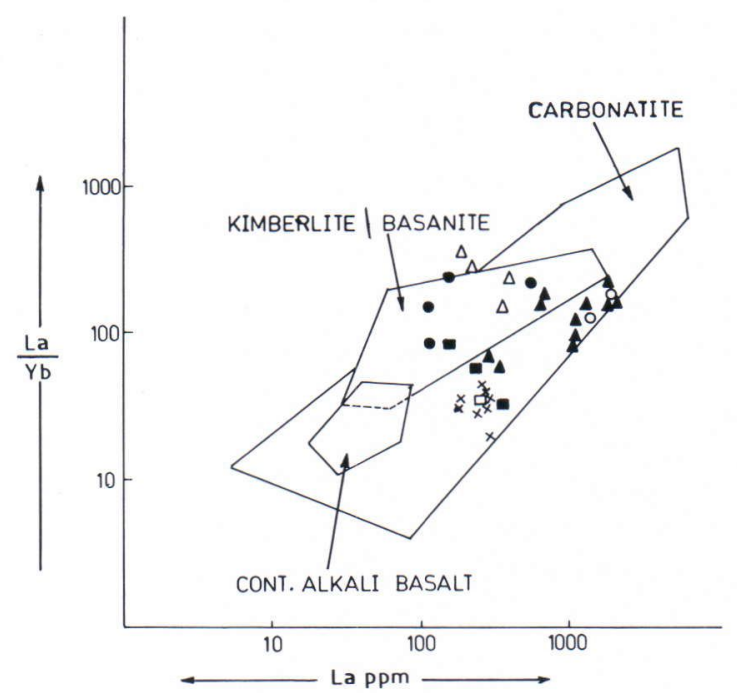

Fig. 7. Plot La/Yb vs La concentrations for carbonatites and apatite of Newania, and carbonatites of Amba Dongar, Sarfartoq and Fen: open circles - Newania apatites; filled circles - Newania carbonatites; open triangles - Sarfartoq rauhaugite and beforsite (Secher \& Larsen, 1980); open square - Fen rauhaugite (Andersen 1987); filled square - Fen rauhaugite (Mitchell and Brunfelt 1975); crosses - Fen sövites (Andersen 1987); filled triangles - Amba Dongar sövites (Viladkar and Dulski 1986); Carbonatite, kimberlite/basanite and cont. alkali basalt field boundaries are taken from Andersen (1987, Fig. 3).

grading variously into sövite and rödberg and it may have been affected by at least one phase of metasomatism».

In comparison to the Newania dolomitic carbonatite Sarfartoq rauhaugite and beforsite show higher total REE abundances. It is interesting to note here that, as at Newania, the highest total REE abundances in Sarfartoq are seen in pyrochlore rich carbonatite (Secher and Larsen 1980).

In the La against La/Yb plot (Fig. 7) dolomitic carbonatites of Newania show wide scatter and most of them fall in the upper part of the carbonatite field which also contain kimberlite/ basanite (Wass and Rogers 1980). The Sarfartoq rauhaugites plot quite close to the Newania dolomitic carbonatites while rauhaugites from the Fen complex (Mitchell and Brunfelt 1975; Andersen
1987) fall away from the carbonatites of these two areas in the lower part of the carbonatite field. There are no sövites in Newania; however, sövites from another Indian carbonatite complex (Amba Dongar) are plotted along with the Fen sövites for comparison. The majority of the Amba Dongar sövites fall away from the dolomitic carbonatites with much lower $\mathrm{La} / \mathrm{Yb}$ ratio.

During fenitization of the granite-gneiss REEs have been added in the increasing order from the mildly fenitized granite-gneiss to the syenitic fenites. The samples collected close to the carbonatite contact are more enriched in total REEs. Eby (1975) suggested that during fenitization Eu is added in relation to other REEs. The present study supports this observation as the unfenitized granite-gneiss shows negative Eu anomaly while the mildly fenitized gneiss shows a small positive Eu anomaly. However, the strongly fenitized rocks (syenitic fenites) do not show any positive Eu anomaly. All syenitic fenites (4, 6 and $9 \mathrm{Ne}$ ) show parallel chondrite normalized distribution patterns of REEs indicating coherent behaviour of REEs during fenitization. The present work confirms the earlier findings of different workers that the REEs are mobile during the fenitization process and that LREEs are added in greater abundance than HREEs to fenites (Martin et al. 1978; Mitchell and Brunfelt 1975; Viladkar and Dulski 1986).

The hypotheses which have been suggested to account for the origin of carbonatites are formation 1) by the fractional crystallization of alkaline ultrabasic magma (Watkinson and Wyllie 1971), 2) by liquid immiscibility between carbonate and silicate fractions (Koster van Groos and Wyllie 1973; Freestone and Hamilton 1980), and 3) as a primary magma originating in the mantle (Koster van Groos 1975).

In the present case the first two possibilities are ruled out as there are no alkaline rocks associated with carbonatites of Newania and neither are there any indications of their being present at depth. This leads us to believe that the dolomitic carbonatite magma of Newania represents a 
primary magma originating in the mantle. It has been suggested by Eggler (1976a, b) and Wyllie and Huang $(1975 a, b)$ that at about 25 kbar pressures and $1200^{\circ}$ C. temperature, primary carbonatitic melts can be derived by small degree of partial melting of carbonated mantle peridotite and that this melt can be REE enriched (Wendlandt and Harrison 1979). Thus the mantle derived dolomitic carbonatite magma of Newania was emplaced higher up in the crust where the ankeritic fraction differentiated. Its emplacement was without any reaction with the crustal rocks. Had there been such a reaction then, as suggested by Koster van Groos (1975),

\section{References}

Andersen, T., 1987. Mantle and crustal components in a carbonatite complex, and the evolution of carbonatite magma: REE and isotopic evidence from the Fen complex, Southeast Norway. Chem. Geol. 65, 147-166.

Deans, T. \& Powell, J. L., 1968. Trace elements and strontium isotopes in carbonatite, fluorites and limestones from India and Pakistan. Nature 218, 750-752.

Eby, G. N., 1975. Abundances and distribution of the rare earth elements and yttrium in the rocks and minerals of the Oka carbonatite complex, Quebec. Geochim. Cosmochim. Acta 39, 597-620.

Eggler, D. H., 1976a. Composition of the partial melt of carbonated peridotite in the system $\mathrm{CaO}-\mathrm{MgO}-\mathrm{SiO}_{2}-\mathrm{CO}_{2}$. Carnegie Inst. Washington Yearb. 75, 623-626.

,- 1976 b. Does $\mathrm{CO}_{2}$ cause partial melting in the low velocity layer of the mantle? Geology. 4, 69-72.

Freestone, I. \& Hamilton, D. L., 1980. The role of liquid immiscibility in the genesis of carbonatites- an experimental study. Contrib. Mineral. Petrol. 73, 105-117.

Koster van Groos, A. F., 1975. The effect of high $\mathrm{CO}_{2}$ pressures on alkalic rocks and its bearing on the formation of alkalic ultrabasic rocks and the associated carbonatites. Am. J. Sci. 275, 163-185.

— \& Wyllie, P. J., 1973. Liquid immiscibility in the join $\mathrm{NaAlSi}{ }_{3} \mathrm{O}_{8}-\mathrm{CaAl}_{2} \mathrm{Si}_{2} \mathrm{O}_{8}-\mathrm{Na}_{2} \mathrm{CO}_{3}-\mathrm{H}_{2} \mathrm{O}$. Am. J. Sci. 273, $465-487$.

Martin, R. F.; Whitley, J. E. \& Woolley, A. R., 1978. An investigation of rare earth mobility: Fenitized quartzites, Borralan Complex, N. W. Scotland. Contrib. Mineral. Petrol. 66, 69-73. there should be ijolitic and sövitic fractions associated with the dolomitic carbonatites.

The Newania carbonatite, therefore, may be taken as a fine example of a mantle derived primary dolomitic carbonatite which was emplaced without crustal contamination. Strontium isotope data $\left({ }^{87} \mathrm{Sr} /{ }^{86} \mathrm{Sr}=0.7034\right.$, and 0.7021 , Deans and Powell 1968) supports its mantle derived origin, although more isotopic data are needed to confirm this conclusion.

Acknowledgement. SGV thanks Dr. M. J. Le Bas for discussions.
Mitchell, R. H. \& Brunfelt, A. O., 1975. Rare earth element geochemistry of the Fen alkalic complex, Norway. Contrib. Mineral. Petrol. 52, 247-259.

Murali, A. V.; Pawaskar, P. B.; Reddy, G. R.; Subbarao, K. W.; Vasudev, V. N. \& Sankar Das, M., 1979. Petrogenetic significance of rare earth element patterns of selected samples of Ingaldhal metavolcanics, Karnataka State, India. Geol. Soc. India, Consortium Studies 1, 20, $334-338$.

Phadke, A. V. \& Jhingran, A. G., 1968. On the carbonatites at Newania, Udaipur district, Rajasthan. J. Geol. Soc. India. 9, 165-169.

Secher, K. \& Larsen, L. M., 1980. Geology and mineralogy of the Sarfartoq carbonatite complex, southern West Greenland. Lithos 13, 199-212.

Viladkar, S. G., 1980. The fenitized aureole of the Newania carbonatite, Rajasthan. Geol. Mag. 117, 285-292.

— \& Dulski, P., 1986. Rare earth element abundances in carbonatites, alkaline rocks and fenites of the Amba Dongar complex, Gujarat, India. N. Jb. Miner. Mh. 1, 37-48.

— \& Wimmenauer, W., 1986. Mineralogy and geochemistry of the Newania carbonatite-fenite complex, Rajasthan, India. N. Jb. Mineral. Abh. 156, 1-21.

Wass, S. Y. \& Rogers, N. W., 1980. Mantle metasomatismprecursor to continental volcanism. Geochim. Consmochim. Acta 44, 1811-1823.

Watkinson, D. H. \& Wyllie, P. J., 1971. Experimental study of the composition join $\mathrm{NaAlSiO}_{4}-\mathrm{CaCO}_{3}-\mathrm{H}_{2} \mathrm{O}$ and the genesis of alkalic rock-carbonatite complexes. J. Petrol. 12, 357-378.

Wendlandt, R. F. \& Harrison, W. J., 1979. Rare earth partitioning between immiscible carbonate and silicate liquids 
and $\mathrm{CO}_{2}$ vapour: Results and implications for the formation of light rare earth enriched rocks. Contrib. Mineral. Petrol. 69, 409-419.

Woolley, A. R., 1982. A discussion of carbonatite evolution and nomenclature, and the generation of sodic and potassic fenites. Miner. Mag. 46, 13-17.

Wyllie, P. J. \& Huang, W. L., 1975a. Influence of mantle $\mathrm{CO}_{2}$ in the generation of carbonatites and kimberlites.
Nature 257, 297-299.

—, 1975b. Peridotite, kimberlite and carbonatite explained in the system $\mathrm{CaO}-\mathrm{MgO}-\mathrm{SiO}_{2}-\mathrm{CO}_{2}$. Geology 3, 621624.

Received November 11, 1988

Revision accepted January 28, 1989 